Original Research Paper

\title{
Biophysic Factors Related to a Local Famous Sweet Potato Variety (Ipomoea batatas L.) Production: A Study Based on Local Knowledge and Field Data in Indonesia
}

\author{
${ }^{1,2}$ Muhammad Amir Solihin, ${ }^{3}$ Santun R.P. Sitorus, ${ }^{3}$ Atang Sutandi and ${ }^{3}$ Widiatmaka \\ ${ }^{I}$ Department of Soil Science and Land Resources, Universitas Padjadjaran, Jatinangor, Indonesia \\ ${ }^{2}$ Doctoral Student, Study Program of Soil Science, Institute Pertanian Bogor, Bogor, Indonesia \\ ${ }^{3}$ Department of Soil Science and Land Resources, Institute Pertanian Bogor, Bogor, Indonesia
}

\author{
Article history \\ Received: 16-06-2016 \\ Revised: $14-10-2016$ \\ Accepted: 20-10-2016 \\ Corresponding Author: \\ Muhammad Amir Solihin \\ Department of Soil Science and \\ Land Resources, Universitas \\ Padjadjaran, Jatinangor, \\ Indonesia and \\ Doctoral Student, Study \\ Program of Soil Science, \\ Institute Pertanian Bogor, \\ Bogor, Indonesia \\ Email: solihinstudentipb@gmail.com
}

\begin{abstract}
Cilembu sweet potato is one of the famous local sweet potatoes in Indonesia. The aim of this study is to determine biophysic factors related to Cilembu sweet potato production based on local knowledge and field data. The research was conducted between September 2014 and October 2015. The methods used simple analytical hierarchy processes and selection guide of land use requirements for local knowledge exploration and Pearson correlation for biophysic factors related to Cilembu production. The samples of study include expert farmers, sweet potatoes and soil samples were selected using purposive sampling technique. The samples of soil and sweet potato were collected during harvest from each cultivation field. The result showed that soil and climate are the dominant environmental factors affecting Cilembu sweet potato production based on farmer perceptions. Correlation analysis confirms the farmers' perception analysis and the field data shows that soil and climate factors have significance correlation to yield and sugar content of Cilembu production. This study is useful for preliminary stage of local varieties land suitability criteria development, more so in the situation of limited data and expertise on the topic.
\end{abstract}

Keywords: Sweet Potato, Cilembu, Local Knowledge, Biophysic Factor, Yield, Sugar Content

\section{Introduction}

Sweet potatoes (Ipomoea batatas L.) are planted widely in tropical and sub-tropical regions. They are rich in carbohydrate, starch, mineral, vitamin, protein and $\beta$ carotene contents (Ziska et al., 2009; Rose and Vasanthakaalam, 2011; Maria and Rodica, 2015). Sweet potatoes production in Indonesia is quite high, reaching the top 4 ranking in the world (FAOSTAT, 2013). One of the most famous local sweet potatoes in Indonesia is the Cilembu sweet potatoes from Cilembu village, Sumedang Regency (DGIP, 2013). The unique feature of Cilembu sweet potatoes is its sweet flavor, originating from the sugary liquid in its tuber, raw or cooked (Onggo, 2006).

Previous studies conducted on Cilembu sweet potatoes, using the Nirkum variety, had revealed that, there is an increase in Nirkum sweet potatoes production in the areas outside its origin area; however, its degree of sweetness is less compared to the original areas (Arifin, 2002; Tohidin, 2006). The variety commonly planted by farmers among 17 varieties in Cilembu Village is Cilembu (Waluyo et al., 2011) and its replacing the Nirkum variety. To find out the appropriate kind of land to cultivate Cilembu sweet potatoes, inorder to produce optimal yield, a land-suitability evaluation is needed.

However, there is no inadequate information on land suitability criterion for the Cilembu sweet potatoes commodity. The available land suitability criterion in Indonesia refer to the suitability criteria for common sweet potatoes (Ritung et al., 2011; Hardjowigeno and Widiatmaka, 2011). These criteria are determined based on expert's perception as expert model approach (De la Rosa and Van Diepen, 2002; Rositter, 2003) and may not conform to the real production condition in the field. The environmental factors will affect the productivity and the sweetness of 
Cilembu sweet potatoes cultivation. It is deal with previous study of sweet potatoes (Bareja, 2011; Neduncheshiyan et al., 2012).

Generally, the production reference in land suitability evaluation is in the form of physical production (yield at harvest). The Framework of Land Evaluation of FAO which release in 1976 stated that land evaluation contains indicators of result or benefit for conducting the evaluation. Therefore, the indicators of production can take the forms of the quality of the commodity's yield in accordance with the market's preference (FAO, 2007). To satisfy market's preferences, the cultivation of Cilembu sweet potatoes considers the production yields and the quality of the harvest in terms of its sugar content (sweetness degree). To develop these criteria for Cilembu sweet potatoes, the characteristics of the land, which affects the yields of production and the sugar content of the harvest, are needed.

Ziadat and Sultan (2011) considered local knowledge, such as the perception of expert farmers, to improve the land suitability criteria. Ebregt et al. (2004) utilized farmers' knowledge to create a pest-control strategy for sweet potatoes cultivation. Farmers with expertise in cultivating Cilembu sweet potatoes can provide local knowledge in the effort to discover the relationship between biophysic factors and Cilembu sweet potatoes production. It is deal with Sojayya (2005) study resulted in Thailand. The exploration of local knowledge by implementing Analytical Hierarchy Process (AHP) can be implemented to construct the primary biophysic factors of the land related to the production of Cilembu sweet potatoes. AHP has been used in land evaluation, before (Ziadat and Sultan, 2011; Sharififar et al., 2012; Yi and Wang, 2013; Mobaraki et al., 2014; Nazeri et al., 2014).

Abushnaf et al. (2013) employed AHP and weighting technique to see the difference in the results of land evaluation criteria. They further stated that this method enables the decision makers or local experts to assign weight value for land factors in accordance with their perception and experience. This is one implementation of expert model to produce land factors for land suitability. In this study, weight of each biophysic factor is determined using the land characteristic selection guide for the land suitability critera in land evaluation developed by FAO. Land characteristic evaluation for land suitability criteria considers these aspects: Importance, critical value and data availability in the field (FAO, 1984; Rositter, 1994).

The identification of land characteristics by using the farmers' perception is confirmed by the field observation. The field observation is conducted to explore the distribution and the performance of production in the existing cultivation area and to make an inventory of land characteristic in terms of soil, climate, topography and hydrology (Hardjowigeno, 2007). Environmental variation in single characteristics plays a role in the sweet potatoes production (Ramirez 1995, O'Sullivan et al., 1997; Belehu and Hammes, 2004; Gomes et al., 2005; Caliskan et al., 2007; Bareja, 2011; Neduncheshiyan et al., 2012; Laxminarayana and John, 2014; Prabawardani and Suparno, 2015). Other factors are variety (Onggo, 2006; Liu et al., 2013; Lai et al., 2013; Kwarteng et al., 2014) and pest, particularly sweet potato weevil (Smith, 2006; Swamy and Omwenga, 2014; Hue and Low, 2015).

Based on the background outlined above, this study is conducted to discover the biophysic factors of soil, in their relation with the performance of yield and sugar content of Cilembu sweet potato in several cultivation areas in West Java. The identification of biophysic factors is conducted through expert's perspective model using the local knowledge of farmers. It is also supported by field observation through production sampling and collection of biophysic data in each cultivation area. The result of this study is expected to provide data concerning the biophysic factors, which are related to the yield production and sweetness degree of Cilembu sweet potatoes.

\section{Methodology}

\section{Description of Research Area}

The field survey was conducted in cultivation areas of Cilembu sweet potatoes, managed by sweet potato farmers in West Java. The areas include: Sumedang (Cilembu Pamulihan, Rancakalong, Tanjungsari, Sukasari, Jatinagor and Situraja villages), Bandung (Cileunyi, Cicalengka, Banjaran, Cimaung regencies), Kuningan (Ciremai) and Cibadak Sukabumi. The cultivation areas are on rain-fed fields. Referring to the Land map Atlas of Indonesian (CSR, 2000), the cultivation areas are on inceptisols order. The topography of these areas varies, from the flat land to hilly, but all cultivation areas are terraced field. From the perspective of geomorphology, the cultivation areas of Cilembu sweet potatoes are dominantly on volcanic area (Silitonga, 2003). The sample plot of cultivation areas is determined through purposive sampling technique, considering that the cultivation areas of Cilembu sweet potato, as specific local variety, are limited to certain areas. The existing cultivation areas are selected as the field units for taking the sample of raw sweet potato tubers during harvest and the sample of composite soils. The cultivation areas of Cilembu sweet potatoes are displayed in Fig. 1.

Cultivation areas of Cilembu sweet potato in this study are origin and extension location. Cilembu, Nagarawangi, Sawahlega and Campakamulya are the origin areas of Cilembu sweet potato cultivation; while Jatinangor, Cicalengka, Nagreg, Ciremai Kuningan and Cibadak Sukabumi are the non-origin or extension areas of Cilembu sweet potato. 


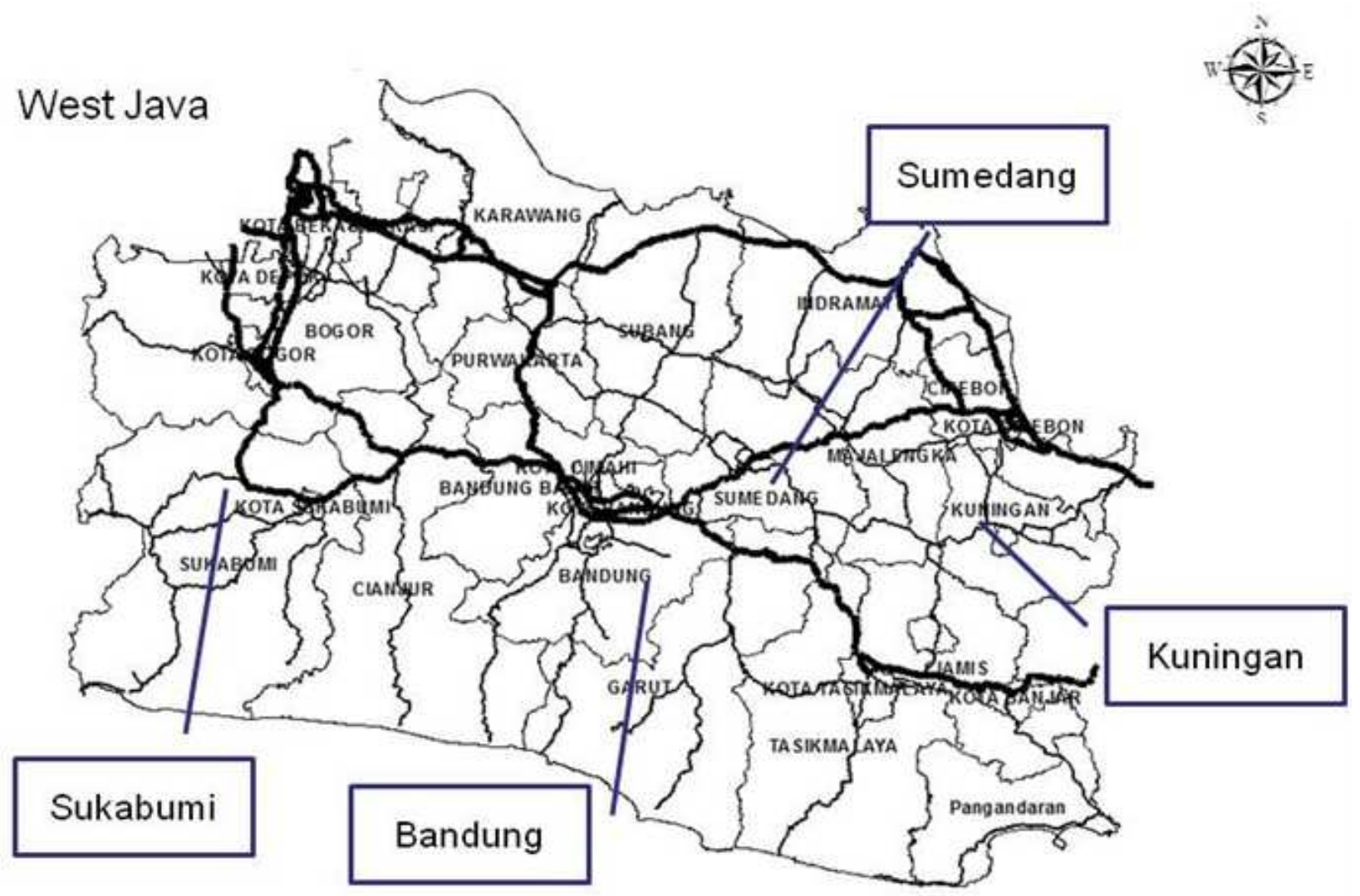

Fig 1. Map of the Cilembu sweet potato production center

\section{Sample of Cilembu Sweet Potato Farmers}

The farmers, who have years of experience in cultivating Cilembu sweet potatoes, was the source of local knowledge to explore the dominant biophysic factors affecting Cilembu production. These experienced farmers are the key sample in this study. The sample of experienced farmers is determined through purposive sampling technique, by considering their experience in cultivating Cilembu sweet potatoes and their great influence over other farmers in Cilembu and the surrounding areas. There were 20 experienced sweet potato farmer samples who did match to farmer sample criteria. The exploration is performed through interviews and semi-open questionnaire. The findings are then confirmed by exploration of land characteristics through field observation and laboratory analysis. The same techniques are implemented by Ziadat and Sultan (2011) and Sojayya (2005) who utilize local condition, including farmers' perception, to improve land suitability criteria.

\section{Cilembu Sweet Potato and its Analysis}

The sample of Cilembu sweet potatoes is harvested at the age of 4.5 months after planting under farmer cultivation from 55 plots of 12 cultivating Cilembu sweet potatoes areas. The production of Cilembu sweet potatoes is measured by the yield per cultivating area and by the sugar content of the raw tubers. The yields production of sweet potatoes is measured in $\mathrm{t} \mathrm{h}^{-1}$ at harvest $(0 \mathrm{WH})$. To obtain data on sugar content, six normal (marketable) tubers are taken from each cultivation plot to be measured at harvest $(0 \mathrm{WH})$.

Lai et al. (2013) revelaed, sucrose is dominant sugar in sweet potato. Brix refractometer used in this study is the digital brix refractometer from Atago pal 1. Prior to the actual measurement, the refractometer is tested to measure the content of $10,20,30$ and $40 \%$ of pure sucrose solution. In each measurement of sugar content of sweet potato, the refractometer is calibrated with distilled water.

\section{Analytical Hierarchy Process (AHP)}

Essentially, AHP is a general theory on measurement used for finding the ratio/scale from discret pair or continuous pair comparisons. These comparisons can be obtained from the actual scale or basic scale representing the power of perception and relative preferences. This method is a framework of effective decision making of a problem by simplifying and accelerating the process through several steps: Breaking down the problem into 
its parts, putting these parts (variables) in a hierarchy, assigning numerical values of subjective opinion concerning the importance of the variable and synthesizing the considerations to determine which variable has highest priority and influence (Vaidya and Kumar, 2006). The implementation of AHP in this study is to facilitate the structuring of biophysical factors that affecting yield and sweetness degree of Cilembu sweet potato from local knowledge (perceptions) of the farmers. The implementation processes are breaking down into variable and criteria of biophysic factors, putting these variables and criteria in hierarchy and assigning value of each variable by farmer's perception. Assigning value of each variable is determined by weighting of land characteristic. The biophysic factors as variable are: Climate, soil, hydrology and topography. The biophysic factors and the land characteristics are explored through interviews with expert farmers. The hierarchy diagram is shown in Fig. 2.

The Consideration for Selecting Land Characteristic in the Development of Land Suitability Criteria

The data from interviews with expert is in weight values for each criteria factor. The weighting of land characteristic related to sweet potato production (yield) is based on FAO (1984), as shown in Table 1.
The weighting on land characteristics is based on the following considerations (FAO, 1984):

- Importance to production of sweet potato

- Large: Sweet potatoes production is particularly sensitive by changes in land properties

- Medium: Sweet potatoes production is quite affected by changes of land properties

- Light or not important: Sweet potatoes production are slight or not affected by land properties

- The occurrence of critical value in the field:

- Frequent: Critical value of land properties often becomes limiting factor

- Sometimes: Critical value of land properties sometimes becomes limiting factor

- Rarely or never: Critical value of land properties rarely or never become limiting factor

- Ease of obtaining the data or information:

- Obtainable: Data or information needed for assessment of land properties is either easy available or easy obtained by existing maps, records or field survey

- Unobtainable: It is not easy or practicable to obtain data or information

Table 1. Weighting of land characteristic related to Cilembu sweet potato production

\begin{tabular}{lllll}
\hline Importance value & Critical value & Ease of data & Significance & Weight \\
\hline Large & Frequent & Obtainable & Very important & 4 \\
Medium & Frequent & Obtainable & Moderately important & 3 \\
Large & Sometimes & Obtainable & Moderately important & 3 \\
Medium & Sometimes & Obtainable & Rather important & 2 \\
Light or Nil & Any & Any & Less important & 1 \\
Any & Rarely or Never & Any & Less important & 1 \\
Any & Any & Unobtainable & Less important & 1 \\
\hline
\end{tabular}

Note: Modification from FAO (1984)

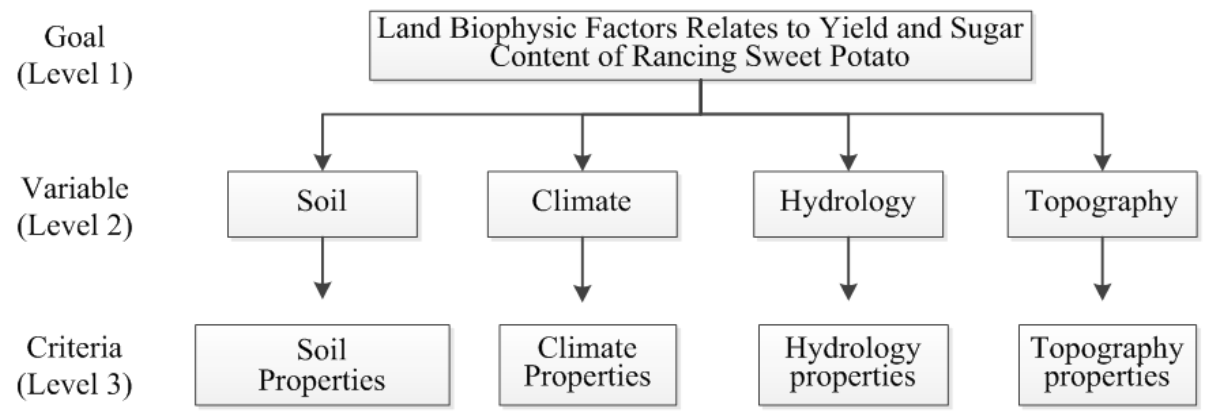

Fig 2. Analytical hierarchy diagram for structuring biophysic factors of land related to yield and sugar content of Cilembu sweet potato 


\section{Soil Sample and its Analysis}

Biophysic factor in this study is referring to land characteristic term of FAO $(1984 ;$ 2007). Land characteristic determined based on the soil characteristic, climate, topgraphic and elevation. The land data samples were taken at 55 plots from 12 Cilembu sweet potato cultivation areas in West Java. The climate data is obtained from the nearest climate (weather) station, while the elevation data is collected through GPS using GPS Garmin 76Csx, in the field and topography map. In each sample location, three plots of cultivation area representative are selected. Composite soil sample is collected from five to ten locations in a plot diagonally, combined with quarter method. Each sample is $1 \mathrm{~kg}$. The soil analysis is performed in soil laboratory of the Agriculture Faculty of Padjadjaran University and Vegetables Research Center of the Indonesian Agricultural Research and Development Center. The analysis is conducted based on the technical procedure of soil analysis from Central for Soil Research of Indonesia (CSR, 2009). Some of the characteristics are measured in the field, including elevation, soil effective depth, surface rocks and rock outcrops. The climate data are air temperature and rainfall during the growth period of Cilembu sweet potato. The relationship (correlation) between land characteristics and Cilembu sweet potato production is analyzed using Pearson correlation and descriptive analysis.

\section{Findings}

Cilembu sweet potato analyzed in this study is Rancing variety. Waluyo et al. (2011) found 17 varieties of sweet potatoes in the cultivation areas in Cilembu village. However, the Rancing variety is the most intensively cultivated by sweet potato farmers in the research sites. Cilembu farmers, cooperating with local farmers of other areas, introduce Cilembu sweet potato cultivation techniques to new cultivating areas. The farmers obtain the local knowledge from their understanding and experiences in cultivating Cilembu sweet potato on the field. This variety of sweet potato is commonly cultivated on rainfed fields, usually during the post-harvest season of rice. It is also possible to cultivate Cilembu sweet potatoes on upland field.

\section{Biophysic Factors Affecting Production of Cilembu Sweet Potato Based on Local Knowledge}

Identification of biophysic factors related to production of Cilembu sweet potato is explored through the perception of expert farmers as the source of local knowledge. The exploration is in the forms of survey, observation and interviews with Cilembu sweet potato farmers who are considered expert and experienced. Although there are many Cilembu sweet potato farmers, only 20 of them are considered expert, experienced and great influential to other farmers. All respondents are farmers who have been continuously, for more than five years, cultivating Cilembu sweet potato. The hierarchy diagram of biophysic factors as shown in Fig. 2 .

Referring to the objective of analytical hierarchy process in this study, the criteria level is the land characteristics which related to the production of Cilembu sweet potato. Based on the result of analysis and total weight of score of biophysic factors (Fig. 3), Soil is the dominant factor related to production of Cilembu sweet potato with total weight of score is 80 , followed by climate with total weight of score is 63 . The soil characteristics that are mostly perceived by the farmer perceptions as related to production of Cilembu sweet potato are soil texture and soil chemical properties. The climate characteristics that are mostly farmers perceived are rainfall and air temperature properties. Topography and hydrology total weight of score are 26 and 20, respectively. Other factors not include in biophysic analysis that the farmers perceive as affecting production are the sweet potato variety and pest attack.

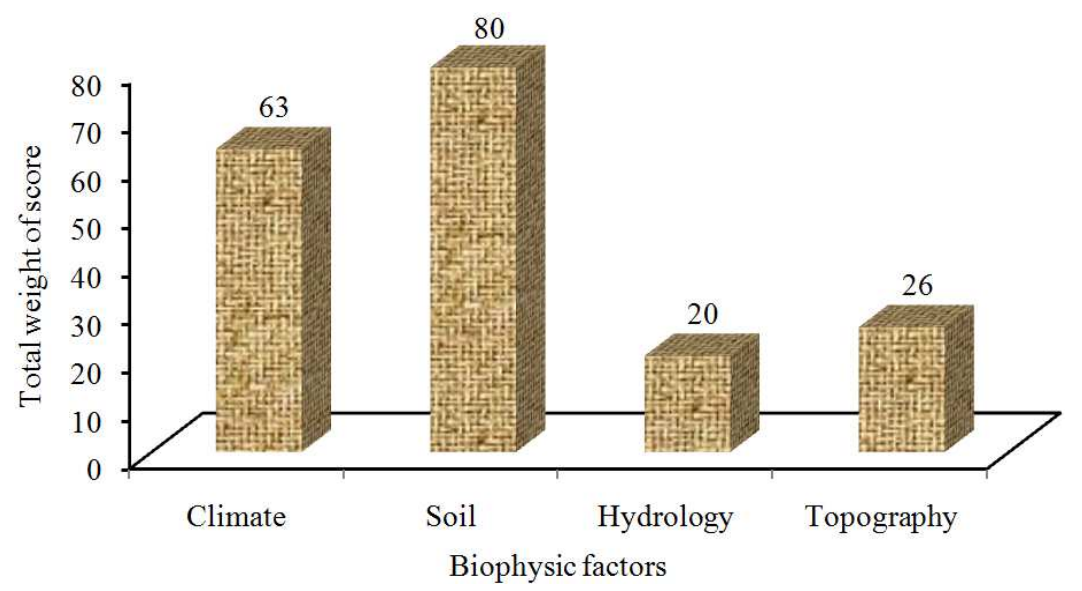

Fig. 3. Biophysic Factors related to the Production of Cilembu Sweet Potato based on farmers' Perception 


\section{Biophysic Factors Relating Production of Cilembu Sweet Potato Based on Field Data}

Field datas were collected from each cultivation location samples while raw tuber samples of sweet potatoes at harvest were taken. Soil chemical data are $\mathrm{pH}$, Soil Organic Carbon (SOC), soil nitrogen $(\mathrm{N})$, available phosphorus $(\mathrm{P})$, total potassium in soil $\left(\mathrm{K}_{2} \mathrm{O}\right)$, Cation Exchange Capacity (CEC), soil base saturation (BS) and exchangeable base (K, Ca, Mg). Soil physical data are texture of clay, sand and silt, soil effective depth (eff. Depth), surface stoniness (S.Stone) and rock outcrops (Rock). Topograpy data is elevation. Climate data are maximum temperature ( $\mathrm{T}$ Max), minimum temperature ( $\mathrm{T}$ Min), Average of Temperatur ( $\mathrm{T}$ avg.) and rainfall at 1 st to 5 th month after planting (Rf1, Rf2, $\mathrm{Rf3}$, Rf4, Rf5). Data of soil characteristic is displayed in the Table 2 to 4 covered origin cultivation areas and extension cultivation areas.

\section{Correlation of Land Characteristics and Yield of Cilembu Sweet Potato}

Land Characteristics (LC) in the study areas are related to the yield of Cilembu sweet potato, as can be seen from the Pearson correlation ( $\mathrm{r}$ ) displayed in Table 5. There is significant correlation between LC and Cilembu yield at 0.01 and 0.05 levels. The LCs include Cations Exchange Capacity (CEC), Calcium (Ca), Magnesium (Mg), soil effective depth (eff.depth), surface stoiness (Sstone), rock outcrops (Rock), maximum ( $\mathrm{T}$ Max) and minimum ( $\mathrm{T}$ min) temperature and rainfall on the first month after planting $\left(\mathrm{Rf}_{1} \mathrm{mfp}\right)$ of Cilembu sweet potato. The correlation between these LCs and yield of Cilembu sweet potato can be positive or negative. It means that these LCs may increase or decrease the yield of Cilembu sweet potato in order to increasing of their value.

Table 2. Data of soil chemical condition in study areas

\begin{tabular}{|c|c|c|c|c|c|c|c|c|c|c|}
\hline Cultivation & $\mathrm{pH} \mathrm{H} \mathrm{H}_{2} \mathrm{O}$ & $\begin{array}{l}\text { SOC } \\
\%\end{array}$ & $\begin{array}{l}\mathrm{N} \\
\%\end{array}$ & $\begin{array}{l}\mathrm{P} \\
\mathrm{mg} . \mathrm{kg}^{-1}\end{array}$ & $\begin{array}{l}\mathrm{K}_{2} \mathrm{O} \\
\mathrm{mg} .100 \mathrm{~g}^{-1}\end{array}$ & $\begin{array}{l}\text { CEC } \\
\text { cmol. } \mathrm{kg}^{-1}\end{array}$ & $\begin{array}{l}\text { BS } \\
\%\end{array}$ & $\begin{array}{l}\mathrm{K} \\
\text { cmol. } \mathrm{kg}^{-1}\end{array}$ & $\mathrm{Ca}$ & $\mathrm{Mg}$ \\
\hline \multicolumn{11}{|l|}{ Origin areas } \\
\hline Cilembu & 6.13 & 1.30 & 0.20 & 7.25 & 15.43 & 23.61 & 51.27 & 0.46 & 7.73 & 3.62 \\
\hline Rancakalong & 5.96 & 1.77 & 0.29 & 26.61 & 16.80 & 32.71 & 43.17 & 0.08 & 9.86 & 5.61 \\
\hline Sukasari & 6.20 & 1.30 & 0.24 & 8.40 & 17.87 & 26.25 & 64.74 & 0.36 & 9.69 & 6.41 \\
\hline Campakamulya & 5.82 & 1.87 & 0.23 & 5.11 & 13.10 & 26.12 & 45.45 & 0.35 & 6.91 & 4.50 \\
\hline \multicolumn{11}{|l|}{ Extension areas } \\
\hline Jatinangor & 6.94 & 1.23 & 0.26 & 45.83 & 9.13 & 29.12 & 95.01 & 0.17 & 17.22 & 8.97 \\
\hline Cicalengka & 6.97 & 1.23 & 0.20 & 5.53 & 16.07 & 28.56 & 76.25 & 0.21 & 11.98 & 8.29 \\
\hline Cimasuk & 7.31 & 2.43 & 0.23 & 14.91 & 17.73 & 28.61 & 43.15 & 0.42 & 5.93 & 5.69 \\
\hline Dangdeur & 7.22 & 0.83 & 0.21 & 35.20 & 8.70 & 32.14 & 88.51 & 0.05 & 15.39 & 12.05 \\
\hline Ciremai & 7.62 & 1.23 & 0.28 & 49.82 & 17.63 & 13.40 & 104.14 & 0.12 & 9.76 & 3.19 \\
\hline Cinunuk & 7.19 & 1.47 & 0.32 & 6.55 & 5.13 & 16.00 & 58.82 & 0.01 & 6.78 & 2.60 \\
\hline Nagreg & 7.01 & 0.70 & 0.22 & 2.92 & 21.73 & 10.87 & 70.41 & 0.28 & 5.13 & 2.14 \\
\hline Sukabumi & 7.15 & 1.81 & 0.19 & 9.16 & 7.42 & 28.29 & 30.40 & 0.14 & 5.41 & 2.75 \\
\hline
\end{tabular}

Table 3. Data of soil physic conditions in study areas

\begin{tabular}{|c|c|c|c|c|c|c|c|}
\hline Cultivation & $\begin{array}{l}\text { Clay } \\
\% \\
\end{array}$ & $\begin{array}{l}\text { Sand } \\
\mathrm{cm}\end{array}$ & $\begin{array}{l}\text { Silt } \\
\mathrm{m} \text { asl }\end{array}$ & $\begin{array}{l}\text { Eff. Depth } \\
(\%)\end{array}$ & $\begin{array}{l}\text { Elevation } \\
\%\end{array}$ & S.Stone & Rock \\
\hline \multicolumn{8}{|l|}{ Origin areas } \\
\hline Cilembu & 41.00 & 8.00 & 51.00 & 100 & 933.64 & 0 & 0 \\
\hline Rancakalong & 51.33 & 13 & 35.67 & 100 & 863.37 & 0 & 0 \\
\hline Sukasari & 52.67 & 4.67 & 42.67 & 100 & 904.80 & 0 & 0 \\
\hline Campakamulya & 49.33 & 10.33 & 40.33 & 100 & 955.91 & 0 & 0 \\
\hline \multicolumn{8}{|l|}{ Extension areas } \\
\hline Jatinangor & 53 & 6.33 & 40.67 & 100 & 724.15 & 0 & 0 \\
\hline Cicalengka & 51 & 5.67 & 43.67 & 100 & 760.44 & 0 & 0 \\
\hline Cimasuk & 36 & 5 & 59 & 100 & 948.70 & 0 & 0 \\
\hline Dangdeur & 51.33 & 21.67 & 27 & 100 & 696.03 & 0 & 0 \\
\hline Ciremai & 12 & 62 & 26 & 25 & 756.92 & 15 & 5 \\
\hline Cinunuk & 52 & 5.67 & 42.33 & 100 & 884.45 & 0 & 0 \\
\hline Nagreg & 49.33 & 13.33 & 37.33 & 75 & 933 & 0 & 0 \\
\hline Sukabumi & 63 & 4 & 33 & 100 & 700 & 0 & 0 \\
\hline
\end{tabular}


Table 4. Data of climate condition of study areas at growing period

\begin{tabular}{|c|c|c|c|c|c|c|c|c|}
\hline Cultivation & $\begin{array}{l}\text { T Max } \\
{ }^{\circ} \mathrm{C} \\
\end{array}$ & $\begin{array}{l}\text { T Min } \\
\text { mm.month }\end{array}$ & T Avg. & Rfl & Rf2 & Rf3 & Rf4 & Rf5 \\
\hline \multicolumn{9}{|l|}{ Origin areas } \\
\hline Cilembu & 29.30 & 18.33 & 24.39 & 52.60 & 93.10 & 161.91 & 236.93 & 252.64 \\
\hline Rancakalong & 25.50 & 12.60 & 19.28 & 100 & 181 & 309 & 373 & 417 \\
\hline Sukasari & 30.60 & 14.60 & 24.57 & 43.50 & 83.50 & 327.67 & 425.92 & 224.83 \\
\hline Campakamulya & 26.10 & 13.80 & 20.04 & 57.10 & 33.10 & 70.30 & 131 & 360.30 \\
\hline \multicolumn{9}{|l|}{ Extension areas } \\
\hline Jatinangor & 30.60 & 15.80 & 24.34 & 83.50 & 327.67 & 425.92 & 224.83 & 208.08 \\
\hline Cicalengka & 28.70 & 16.73 & 22.73 & 27.42 & 36.17 & 81.32 & 181.45 & 290.88 \\
\hline Cimasuk & 27.80 & 15.10 & 21.32 & 0 & 0 & 0 & 0 & 0 \\
\hline Dangdeur & 30.60 & 15.80 & 24.34 & 83.50 & 327.67 & 425.92 & 224.83 & 208.08 \\
\hline Ciremai & 28.80 & 19.70 & 24.12 & 424 & 528 & 456 & 523 & 307 \\
\hline Cinunuk & 27.90 & 18.80 & 23.12 & 234.85 & 245.75 & 305 & 234.63 & 125.63 \\
\hline Nagreg & 27.30 & 18.10 & 22.50 & 299 & 289 & 259 & 313 & 236 \\
\hline Sukabumi & 30.60 & 18.50 & 24.48 & 288 & 184 & 163 & 170 & 197 \\
\hline
\end{tabular}

Table 5. Correlation between land characteristics and the yield of Cilembu sweet potato

\begin{tabular}{|c|c|c|c|c|c|c|c|c|c|c|c|}
\hline \multicolumn{12}{|c|}{ Soil Chemical Properties } \\
\hline $\mathrm{LC}$ & $\mathrm{pH} \mathrm{H} \mathrm{H}_{2} \mathrm{O}$ & SOC & $\mathrm{N}$ & P Olsen & $\mathrm{K}_{2} \mathrm{O}$ & CEC & Al Sat & BS & $\mathrm{K}$ & $\mathrm{Ca}$ & \\
\hline $\mathrm{r}^{\mathrm{a}}$ & $0.113^{2}$ & -0.202 & -0.013 & -0.084 & -08 & $0.392^{* *}$ & -0.132 & -0.52 & 0.08 & $0.284^{*}$ & $0.354^{* *}$ \\
\hline \multicolumn{7}{|c|}{ Soil Physical Properties } & \multicolumn{5}{|c|}{ Topography } \\
\hline $\mathrm{LC}$ & Clay & Sand & Silt & Eff-Depth & Sstone & Rock & Elevatic & & & & \\
\hline $\mathrm{r}^{\mathrm{a}}$ & 0.087 & -0.105 & 0.029 & $0.282^{*}$ & $-0.273^{*}$ & $-0.273^{*}$ & -0.12 & & & & \\
\hline \multicolumn{12}{|c|}{ Climate Properties } \\
\hline $\mathrm{LC}$ & $\mathrm{T}_{\mathrm{Max}}$ & $\mathrm{T}_{\mathrm{Min}}$ & $\mathrm{T}_{\text {Average }}$ & $\mathrm{RF}_{1}$ & $\mathrm{Rf}_{2}$ & $\mathrm{Rf}_{3}$ & $\mathrm{Rf}_{4}$ & $\mathrm{Rf}_{5}$ & & & \\
\hline $\mathrm{r}^{\mathrm{a}}$ & $0.233^{*}$ & $-0.357^{* *}$ & 0.103 & $-0.249^{*}$ & -0.54 & 0.216 & 0.077 & 0.064 & & & \\
\hline
\end{tabular}

Table 6. Correlation between land characteristics and the sugar content of Cilembu sweet potato

\begin{tabular}{|c|c|c|c|c|c|c|c|c|c|c|c|}
\hline \multicolumn{12}{|c|}{ Soil Chemical Properties } \\
\hline $\mathrm{LC}$ & $\mathrm{pH} \mathrm{H} \mathrm{H}_{2} \mathrm{O}$ & SOC & $\mathrm{N}$ & P Olsen & $\mathrm{K}_{2} \mathrm{O}$ & CEC & $\mathrm{Al} \mathrm{Sat}$ & BS & $\mathrm{K}$ & $\mathrm{Ca}$ & \\
\hline $\mathrm{r}^{\mathrm{a}}$ & 0.17 & 0.08 & -0.08 & -0.12 & $-.334^{* *}$ & 0.09 & 0.10 & $-.282^{*}$ & -0.18 & -0.13 & $-.237^{*}$ \\
\hline \multicolumn{3}{|c|}{ Soil Physical Properties } & \multicolumn{9}{|c|}{ Topography } \\
\hline $\mathrm{LC}$ & Clay & Sand & Silt & Eff-Depth & Sstone & Rock & Elevation & & & & \\
\hline $\mathrm{r}^{\mathrm{a}}$ & $.304^{*}$ & $-.297^{*}$ & -0.01 & $.227^{*}$ & -0.06 & $.355^{* *}$ & -0.20 & & & & \\
\hline \multicolumn{12}{|c|}{ Climate Properties } \\
\hline $\mathrm{LC}$ & $\mathrm{T}_{\operatorname{Max}}$ & $\mathrm{T}_{\text {Min }_{*}}$ & $\mathrm{~T}_{\text {Average }}$ & $\mathrm{RF}_{1}$ & $\mathrm{Rf}_{2}$ & $\mathrm{Rf}_{3}$ & $\mathrm{Rf}_{4}$ & $\mathrm{Rf}_{5}$ & & & \\
\hline $\mathrm{r}^{\mathrm{a}}$ & 0.22 & $.297^{*}$ & $.233^{*}$ & 0.21 & 0.02 & -0.06 & -0.19 & -0.15 & & & \\
\hline
\end{tabular}

\section{Correlation Between Land Characteristics and Sugar Content of Cilembu Sweet Potato}

The Land Characteristics (LCs) and the sugar content of Cilembu sweet potato at harvest have significant correlation (Table 6). The LCs include $\mathrm{K}_{2} \mathrm{O}$, Base Saturation (BS), Magnesium (Mg), clay, sand, soil effective depth, rock outrop and minimum and average of temperature. The correlation is positive and negative that every increase in LCs may increase or decrease sugar content of Cilembu sweet potato. The significance level based on T-test is 0.01 and 0.05 .

\section{Discussion}

From the exploration of local knowledge of sweet potato farmers, it is found that the factors of soil and climate characteristics are important for the growth and yield of Cilembu sweet potato. The land characteristics that most farmers perceive as related to production of Cilembu sweet potato are physical and chemical properties of soil, while the climate characteristics include the rainfall and temperature. This finding is congruent with Neduncheshiyan et al. (2012) findings that climate, temperature and soil characteristics relate to the production and growth of sweet potato. The factors of topography and hydrology are less influential to the production of Cilembu sweet potato because the cultivation is generally performed on rainfed terraced fields at the beginning or the end of rainy season. Other factors that farmers deem influential are the sweet potato variety and pests attack. The influence of sweet potato variety on sugar content is noted by Onggo (2006), 
Uwah et al. (2013), Liu et al. (2013), Lai et al. (2013) and Kwarteng et al. (2014), while the effect of sweet potato weevils on production is studied by Smith (2006), Swamy and Omwenga (2014) and Hue and Low (2015).

Although their environmental understanding is relatively simple, the farmers' perception can be used as preliminary identification of land biophysic factors that need to be considered in the cultivation of Cilembu sweet potato. Ziadat and Sultan (2011) and Sojayya (2005) are utilizing local kvowledges to improve land suitability criteria. The accuracy of evaluation through farmers' perception depends on the local knowledge of expert (experienced) farmer as the key respondent and the skills of the interviewer to explore their knowledge in accordance with the structure of the problems in analytical hierarchy process. However, local knowledge is an important source to identify biophysic factors of land relating to sweet potato cultivation when the availability of data and expert is limited. The weakness of these farmers' perception is their general exploration of land characteristic variable, due to their limited scientific knowledge.

Based on field data and sweet potato production correlation analysis is congruent to result of local knowledge analysis. Soil, climate and topography are biophysic factors related to the yield and sugar content of Cilembu sweet potato. The LCs are Cations Exchange Capacity (CEC), Calcium (Ca), Magnesium (Mg), clay, sand, soil effective depth, surface stoiness, rock outcrops, maximum and minimum temperature and rainfall at the first month after planting $\left(\mathrm{Rf}_{1} \mathrm{mfp}\right)$. The LCs related to sugar content are $\mathrm{K}_{2} \mathrm{O}$, base saturation (BS), Magnesium (Mg), clay, sand, soil effective depth, rock outcrops and temperature at minimum and average.

Both of yield production and sugar content of Cilembu sweet potato are relate to soil chemical, soil physical and climate properties. Fertilty of soil is determined by chemical and physical condition. Cultivation of Cilembu sweet potato in the studied area is mostly performed at volcanic soil areas. The volcanicash soil produces short-ordered and easily-decayed minerals (Wada, 1987) and possesses higher level of CEC, compared with soil from ingenious rocks (Tan, 1998; Hardjowigeno, 2007). The decayed minerals are the main source of nutrient for plants (Tan, 1998). The lowest yield production is at Nagreg cultivation area, with the yield about $8-15 \mathrm{t} \mathrm{h}^{-1}$. The soil in Nagreg area has the lowest CEC level among all the cultivation areas. Low CEC indicates low fertility. Consequently, the growth of the plants is not optimal and the yield decreases. Low CEC may also be related to the low organic-soil in Nagreg area. Beside CEC, Base Saturation (BS) is also related to soil fertility (Hardjowigeno, 2007). The soils in the studied area generally have moderate to high $\mathrm{BS}$. It is possible because the volcanic soils in the areas are mostly basaltic, so that their decay produces high base cations than andesitic or mafic parent material. High BS is related to the availability of essential nutrients such as K, $\mathrm{Ca}$ and $\mathrm{Mg}$, which are Cilembu sweet potato.

The yield and sugar content of Cilembu sweet potato correlate significantly with Magnesium. Mostly, the cultivation areas in this study have lower level of $\mathrm{Mg}$ in soil, compared with the highest level of $\mathrm{Mg}$ in soil and highest yield in Dangdeur. Hardjowigeno (2007) noted that magnesium in plants plays important role in chlorophyll production and as co-factor of various enzymes. Significant correlation between $\mathrm{Mg}$ and sugar content of Cilembu sweet potato is related to the support more optimal photosynthesis and the bio-chemical processes in plants. Sufficient amount of $\mathrm{Mg}$ in the soil increases the sugar content in plants. This is congruent with the findings of Laxminarayana and John (2014) on the influence of $\mathrm{Mg}$ in Alfisol on increasing of sugar content.

Potassium correlates negatively and significantly with sugar content. Potassium is important for distribution of photosynthate in tubers (Prabawardani and Suparno, 2015; Liu et al., 2013). Sucrose is a product of photosynthesis that is translocated (Ayre, 2011). Tohidin (2006) stated that Potassium significant affect to sugar content in Nirkum Cilembu sweet potato. However, overabundance of $\mathrm{K}_{2} \mathrm{O}$ in the soil tends to cause deficiency of $\mathrm{Mg}, \mathrm{Ca}$ and $\mathrm{B}$, as O'Sullivan et al. (1997) stated. Hardjowigeno (2007) stated, although total potassium in soil is high, availability for plant in soil is low. High level of $\mathrm{K}_{2} \mathrm{O}$ in some areas of Cilembu cultivation may be due to fertilizing process and accumulation of potassium from irrigation system in years. The areas with lower level of $\mathrm{K}_{2} \mathrm{O}$, such as Cibadak and Cinunuk, tend to have higher sugar content than other cultivation areas while the areas are non intensive agriculture land.

Soil texture, particularly clay and sand, correlates significantly with yield and sugar content of Cilembu sweet potato, at a significance level of 0.05 . Soil texture is important for the growth and yield of Cilembu sweet potato because it determines the roots condition. Cilembu sweet potato generally requires sufficient level of water in the soil; although Prabawardani (2007) stated there are some varieties that are dry-resistant. It is proven by the level of yield and sugar content of Cilembu sweet potato at harvest. In Ciremai cultivation area, the yield and sugar content are the lowest, due to the sandy-clay texture of the soil. Meanwhile, the moderate-to-high level of production and sugar content is found in cultivation areas with higher level of clay. Soil with high level of sand is easier to process than soil with high level of clay. However, the water retention ability and capability of sandy soil is low (Wu et al., 
2011; Hardjowigeno, 2007). The correlation of texture and water level in the soil is studied by Tan (1998) and $\mathrm{Wu}$ et al. (2011). Considering the findings, it can be concluded that Cilembu sweet potato prefers higher level of clay and lower level of sand in the soil. Clay soil facilitates the dynamic of adsorption, exchange and nutrient retention in the soil. Meanwhile, sandy soil cannot absorb soil nutrient well.

The effective depth of the soil has significant correlation at a significance level of 0.05 to yield and sugar content of Cilembu sweet potato. This is related to adequate condition at root zone, which include ease to go through the soil and availability of water in the soil. Shallow effective depth and limited volume of root zone will hinder the growth of the top part of the plats (FAO, 1984). It also correlates with surface stoinness and rock outcrops that have negative correlation with sugar content of Cilembu sweet potato at significance level of 0.01. This is congruent with the findings of Arifin (2002), due to lower growth of crop in high soil rockiness than sandy site. In Ciremai cultivation area, the yield and sugar content are the lowest, due to the shallow soil effective depth, high content of surface stoinness and rock outcrops on its soil.

Regarding climate, all areas of cultivation are rainfed fields. Rainfall level at the first month after planting $\left(\mathrm{Rf}_{1}\right)$ correlates significantly with Cilembu yield. This has to do with the timing of initial development (Caliskan et al., 2007). Rainfall level on the rainfed fields is relate to water availability and the leaves' capability to absorp radiation for photosynthesis (Gomes et al., 2005), which in turn will affect the yield of the sweet potato. But sweet potato very sensitif to high rainfall and excess soil water during at the first 20 days from planting and reduced yield (Hartemink et al., 2000). At Cimasuk cultivation area, there is no rain falls during the growth phases of sweet potato, resulting in yield level of $7.67 \mathrm{t} \mathrm{h}^{-1}$, the lowest of all areas. Sweet potato that did not enough water supply from rain during the first month after planting causing significantly decreases the yield (Neduncheshiyan et al., 2012) and the marketable yield of sweet potato (Hartemink et al., 2000). Availability of water in the soil is important to produce soluble solid to be absorbed by the plant (Prabawardani and Suparno, 2015). The effect of water scarcity during dry season not only decreases growth and yield but also increases the possibility of pest, particularly the sweet potato weevil (Cylas, Sp) as stated by Smith (2006), Swamy and Omwenga (2014) and Hue and Low (2015). At Cimasuk cultivation area, around $15 \%$ of yield harvest is unmarketable due to sweet potato weevil.

The other climate factor is temperature. The maximum, minimum and average temperatures in studied areas significantly correlate with yield and sugar content of Cilembu sweet potato at significance level of 0.05 . The lowest temperature is at Cinunuk and Cibadak cultivation area, reaching $18.5-18.8^{\circ} \mathrm{C}$ at night. The high maximum temperature support optimum photosyntesis. Meanwhile, the accumulation of photosynthesis in sweet potato tuber occurs at night, under the temperature of $15-20^{\circ} \mathrm{C}$ (Ramirez, 1995). The average temperature of Cinunuk is $23.12^{\circ} \mathrm{C}$ and in Cibadak is $24.48 \%$. This is in line with findings of Belehu and Hammes (2004) that stated that the temperature of $24^{\circ} \mathrm{C}$ yields the highest weight of dry tubers.

\section{Conclusion}

Land biophysic factors related to the production of Cilembu sweet potato, based on local knowledge and field observation, are important for preliminary development of land suitability criteria for Cilembu sweet potato. The farmers' perception revealed soil and climate is a major biophysic factors related to yield and sweetness degree of Cilembu sweet potato. Soil characteristics that often as limiting factors of sweet potato production are soil texture and soil chemical properties. While climate characteristics are air temperatur and rainfall.

Field study confirms the characterization of land biophysic factors related to the production of Cilembu sweet potato. Soil and climate characteristics related to the yield of Cilembu sweet potato are Cations Exchange Capacity (CEC), Calcium (Ca), Magnesium (Mg), clay, sand, soil effective depth, surface stoinness, rock outcrops, maximum and minimum temperature and rainfall at the first month after planting $\left(\mathrm{Rf}_{1} \mathrm{mfp}\right)$. While the factors related to sugar content are $\mathrm{K}_{2} \mathrm{O}$, Base Saturation (BS), Magnesium (Mg), clay, sand, soil effective depth, rock outcrops, minimum air tempertur and average air temperature. The effort to increase of yield and sugar content of Cilembu sweet potato should consider the land characteristics affecting it. The land characteristics relate to yield and sugar content of Cilembu sweet potato considerable in selecting diagnostic criterion in development of land suitability criteria of Cilembu sweet potato. This study is useful for preliminary stage of Cilembu land suitability criteria development, in the situation of limited data and expertise on the topic

\section{Acknowledgment}

The authors gratefully thank the DGHE, Ministry of Research, Technology and Higher Education, Republic of Indonesia for financial support under program BPPS (2604.E4.4/2012) and doctoral research grant (CN: 431.UN.6.3.1/PL/2016). 


\section{Author's Contributions}

Each of the authors above, played a major role during the process of writing this paper. However, the corresponding author did a wonderful job.

\section{Ethics}

We strictly followed existing academic procedures in writing this paper.

\section{References}

Abushnaf, F.F., K.J. Spence and I.D. Rotherham, 2013. Developing a land evaluation model for the benghazi region in northeast Libya using a geographic information system and multi-criteria analysis. APCBEE Proc., 5: 69-75.

DOI: $10.1016 /$ j.apcbee.2013.05.013

Arifin, M., 2002. Karakterisasi pedon areal pertanaman UBI JALAR nirkum di desa cilembu, kecamatan tanjungsari, kabupaten sumedang, propinsi jawa barat. Bandung (ID). J. Agrikultura, 13: 110-116.

Ayre, B.G., 2011. Membrane-transport systems for sucrose in relation to whole-plant carbon partitioning. Molecular Plant, 4: 377-394. DOI: $10.1093 / \mathrm{mp} / \mathrm{ssr} 014$

Bareja, B.G., 2011. Plant growth factors in relation to crop farming. Tersedia Pada.

Belehu, T. and P.S. Hammes, 2004. Effect of temperature, soil moisture content and type of cutting on establishment of sweet potato cuttings. South African J. Plant Soil, 21: 85-89. DOI: $10.1080 / 02571862.2004 .10635028$

CSR, 2000. Atlas Tanah Explorasi. Central for Soil Research, Balai Penelitian dan Pengembangan Pertanian. Kementerian Pertanian Republik Indonesia, Bogor (ID).

CSR, 2009. Petunjuk Teknis Analisis Kimia Tanah, Tanaman, Air, dan Pupuk. Central for Soil Research, Balai Penelitian Tanah. Balai Penelitian dan Pengembangan Pertanian. Kementerian Pertanian Republik Indonesia.

Caliskan, M.E., T. Sogut, E. Boydak, E. Ertürk and H. Arioglu, 2007. Growth, yield and quality of sweet potato (Ipomoea batatas (L.) Lam.) cultivars in the southeastern Anatolian and east mediterranean regions of turkey. Turk. J. Agri. For., 31: 213-227.

De la Rosa, D. and C.A. Van Diepen, 2002. Qualitative and quantitative land evaluation. In: Encyclopedia of Life Support System, Eolss Publishers, Oxford.

DGIP, 2013. Indikasi Geografis Ubi Jalar Cilembu. Directorate General Intelectual Property, Jakarta (ID), Direktorat Jenderal Hak Kekayaan Intelektual, Kementerian Hukum dan Hak Asasi Manusia Republik Indonesia.
Ebregt, E., P.C. Struik, P.E. Abidin and B. Odongo, 2004. Farmers' information on sweet potato production and millipede infestation in north-eastern Uganda. II. Pest incidence and indigenous control strategies. NJAS, 52: 69-84. DOI: 10.1016/S1573-5214(04)80030-7

FAO, 1984. A guidelines: Land Evaluation for Rainfed Agriculture. FAO Soil Bulletin, Rome (IT).

FAO, 2007. Land evaluation toward revised framework. Food and Agriculture Organization of the United Nations, Rome (IT).

FAOSTAT, 2013. World Commodities Production of Sweet Potato 2012. Di akses pada 3 Maret 2016 tersedia pada laman.

Gomes, F, M.K.V. Carr and G.R. Squire, 2005. Effects of water availability and vine harvesting frequency on the productivity of sweet potato in southern mozambique, radiation interception, dry matter, production and partitioning. Expl. Agric., 41: 93-108. DOI: $10.1017 / \mathrm{S} 0014479704002352$

Hardjowigeno, S., 2007. Ilmu Tanah. Penerbit Akademika Pressindo, Jakarta (ID)

Hardjowigeno, S. and Widiatmaka, 2011. Evaluasi Kesesuaian Lahan Dan Perencanaan Tataguna Lahan. 1st Edn., Gadjah Mada University Press, Yogyakarta (ID), pp: 351.

Hartemink, A.E., S. Poloma, M. Maino, K.S. Powell and J. Eganae et al., 2000. Yield decline of sweet potato in the humid lowlands of Papua New Guinea. J. Agric. Ecosyst. Environ., 79: 259-269. DOI: 10.1016/S0167-8809(00)00139-0

Hue, S.M. and M.Y. Low, 2015. An insight into sweet potato weevils management: A review. Psyche, 2015: 849560-849570. DOI: 10.1155/2015/849560

Kwarteng, E.A., O. Esther, S. Dawson, G.S. Ayernor and Van-Den Truong et al., 2014. Variability of sugars in staple-type sweet potato (Ipomoea batatas L.) cultivars: The effects of harvest time and storage. Int. J. Food. Prop., 17: 410-420.

DOI: $10.1080 / 10942912.2011 .642439$

Lai, Y.C., C.L. Huang, C.F. Chan, C.Y. Lien and W.C. Liao, 2013. Studies of sugar composition and starch morphology of baked sweet potatoes (Ipomoea batatas L.). J. Food Sci. Technol., 50: 1193-9. DOI: 10.1007/s13197-011-0453-6

Laxminarayana, K and K.S. John, 2014 Effect of zinc and magnesium on orange fleshed sweet potato in alfisols of Odisha, India. J. Root Crops, 40: 1-7.

Liu, H., C. Shi, H. Zhang, Z. Wang and C. Shai, 2013. Effects of potassium on yield, photosynthate distribution, enzymes' activity and ABA content in storage roots of sweet potato (Ipomoea batatas Lam.). Australian J. Crop Sci., 7: 735-743.

Maria, D. and S. Rodica, 2015. Researches on the sweet potato (Ipomoea batatas L.) behaviour under the soil and climatic conditions of the South-West of Romania. J. Hortic. Forestry Biotechnol., 19: 79-84. 
Mobaraki, O., M. Abdollahzadeh and Z. Kamelifar, 2014. Site suitability evaluation for ecotourism using GIS and AHP: A case study of Isfahan Townships, Iran. Manage. Sci. Lett., 4: 1893-1898. DOI: $10.5267 /$ j.msl.2014.6.038

Nazeri, Z., J. Mirzaee and A. Rostami, 2014. Application of analytical hierarchy process in land suitability for forest park location (case study: Ilam county, Iran). J. Biodiversity Environ. Sci., 4: 301-309.

Neduncheshiyan, M., G. Byju and S.K. Jata, 2012. Sweet potato agronomy. Fruit Vegetable Sereal Sci. Biotechnol., 6: 1-10.

Onggo, T.M., 2006. Perubahan komposisi pati dan gula dua jenis ubi jalar nirkum "Cilembu" selama penyimpanan. J. Bionatura, 8: 161-170.

O'Sullivan, J.N., C.J. Asher and F.P.C. Blarney, 1997. Nutrien disorder of sweet potato. Australian Centre for International Agricultural Research, Canberra (AU).

Prabawardani, S., 2007. Physiological and growth responses of selected sweet potato (Ipomoea batatas (L.) Lam.) cultivars to water stress. PhD Thesis, James Cook University.

Prabawardani, S. and A. Suparno, 2015. Water use efficiency and yield of sweetpotato as affected by nitrogen and potassium application. J. Agric. Sci., 7: 128-137. DOI: $10.5539 /$ jas.v7n7p128

Ramirez, G.P., 1995. Ciltivation, harvesting and storage of sweet Pototes products. On Root, Tuber, Plantain and Bananas in Animal Feeding.

Ritung, S., K. Nugroho, A. Mulyani and E. Suryani, 2011. Petunjuk teknis evaluasi lahan untuk komoditas pertanian (edisi revisi). Balai Besar Penelitian dan Pengembangan Sumberdaya Lahan Pertanian, Badan Penelitian dan Pengembangan Pertanian. Bogor. 168 hal.

Rositter, D.G., 1994. Land Evaluation. Cornell University, Ithaca New York (US).

Rositter, D.G., 2003. Biophysic Models In Land Evaluation. In: Encyclopedia of Life Support Sstem (EOLSS) section 1.5 Land Use and Land Cover. EOLSS Publishers Co. Ltd, Oxford (UK).

Rose, I.M. and H. Vasanthakaalam, 2011. Comparison of the nutrient composition of four sweet potato varieties cultivated in Rwanda. Am. J. Food Nutrit., 1: 34-38. DOI: 10.5251/ajfn.2011.1.1.34.38

Sharififar, A., H. Ghorbani and H. Karimi, 2012. Integrated land evaluation for sustainable agricultural production by using analytical hierarchy process. Agriculture, 59: 131-14. DOI: 10.2478/agri-2013-0012

Silitonga, P.H., 2003. Peta Geologi Lembar Bandung, Jawa. Departemen Pertambangan Republik Indonesia, Direktorat Geologi, Bandung (ID).

Smith, T.P., 2006. Biology and chemical ecology of sugarcane beetle and integrated pest management of sweet potato soil insects in Louisiana. Louisiana State University and Agricultural and Mechanical College, Lousiana (USA).
Sojayya, P., 2005. Comparison between conventional land evaluation and a method based on farmers' indigenous knowledge: Case study in Lom Sak district, Phetchabun province, Thailand. Enschede, ITC.

Swamy, A.T. and J. Omwenga, 2014. Analysis of phytochemical composition of white and purple sweet potato (Ipomoea batatas [L.] Lam) root. Ind. J. Adv. Plant. Res., 1: 19-22.

Tan, K.H., 1998. Principles of Soil Sciences. 1st Edn., Marcel Dekker Inc. New York. USA.

Tohidin, 2006. Hubungan antara Karakteristik Tanah Sawah Tadah Hujan Berbahan Induk Abu Volkan dengan Kandungan Gula Total Ubi Jalar Nirkum di Beberapa Sentra Ubi Jalar di Jawa Barat. Program Pascasarjana Universitas Padjadjaran, Bandung (ID).

Uwah, D.F., U.L. Undie, N.M. John and G.O. Ukoha, 2013. Growth and yield response of improved sweet potato (Ipomoea batatas (L.) Lam) varieties to different rates of potassium fertilizer in Calabar, Nigeria. J. Agric. Sci., 5: 61-69. DOI: 10.5539/jas.v5n7p61

Vaidya, O.S. and S. Kumarn, 2006. Analytic hierarchy process: An overview of applications. Eur. J. Operat. Res., 169: 1-29. DOI: 10.1016/j.ejor.2004.04.028

Wada, K., 1987. Minerals formed and mineral formation from volcanic ash by weathering. Chem. Geol., 60: 17-28. DOI: 10.1016/0009-2541(87)90106-9

Waluyo, B., S.L. Rahmannisa and A. Karuniawan, 2011. Diversitas morfologi dan fenologi serta ancaman kepunahan terhadap varietas lokal ubi jalar asal Cilembu. Makalah. Dalam: Keanekaan Hayati dan Layanan Ekosistem. Seminar Nasional; 20 September 2011; Bandung, Indonesia. Bandung (ID). Jurusan Biologi FMIPA Unpad, Program Studi Magister Ilmu Lingkungan Program Pascasarjana Unpad, The University of Tokyo dan Himpunan Mahasiswa Biologi FMIPA Unpad.

Wu, Y., M. Huang and J. Gallichand, 2011. Transpirational response to water availability for winter wheat as affected by soil textures. Agric. Water Manage., 98: 569-576. DOI: 10.1016/j.agwat.2010.10.015

Yi, X. and L Wang, 2013. Land suitability assessment on a watershed of loess plateau using the analytic hierarchy process. PLoS ONE, 8: 94-98. DOI: 10.1371/journal.pone.0069498

Ziadat, F.M. and K.A. Sultan, 2011. Combining current land use and farmers' knowledge to design land-use requirements and improve land suitability evaluation. J. Renewable Agric. Food Syst.., 26: 287-296. DOI: $10.1017 / \mathrm{S} 1742170511000093$

Ziska, L.H., G.B. Grunion, M. Tomecek, S.A. Prior and H.A. Torbet et al., 2009. An evaluation of cassava, sweet potato and field corn as potential carbohydrate sources for bioethanol production in Alabama and Maryland. Biomass Bioenergy, 33: 1503-1508.

DOI: 10.1016/j.biombioe.2009.07.014 